У,AK 331

ББК 65.24

DOI 10.22394/1682-2358-2018-4-88-94

O.Yu. Tarskaya, Doctor of Sciences (Sociology), Povolzhsky Institute of Management named after P.A. Stolypin, Branch of the Russian Presidential Academy of National Economy and Public Administration

O.V. Kbambikov, Colonel of Internal Service, Head of the FSI «3rd Detachment of the Federal Fire-Fighting Service in the Saratov Region"

\section{SOCIOCULTURAL CONTEXTS OF ADAPTATION TO THE GLOBALIZATION OF LABOR MARKETS}

The globalization processes of labor markets adaptation, as well as staffing problems of municipal territories investment development are analyzed. The priorities of the state educational and labor policy are determined. Conclusions are drawn, and proposals on the need to reconfigure the state management of educational systems in the context of labor market requests are formulated.

Key words and word-combinations labor market, globalization processes, sociocultural contexts, educational practices, public administration.
О.Ю. Тарская, доктор сочиологиеских наук, профессор кафедри сочиологи и сочиальной политики Поволжского института управления имени П.А. Стольтпина - филиала Российской академии народного хозяйства и государственной служби при Президенте РФ (email: tarskayaolga@ mail.ru)

О.В. ХамбикоВ, полковник внутренней службьи, начальник ФГКУ «3 отряд ФПС по Саратовской области» (email: tarskayaolga@mail.ru)

\section{СОЩИОКУАЬТУРНЫЕ КОНТЕКСТЫ АААПТАЦИИ К ГАОБААИЗАЦИИ PЫHKA TPУAA}

\footnotetext{
Аннотация. Анализируются глобализационные процессы адаптации рынка труда, проблемы кадрового обеспечения инвестиционного развития муниципальных территорий. Определяются приоритеты государственной образовательной и трудовой политики. Формулируются выводы и предложения о необходимости совершенствования государственного управления образовательными системами в контексте запросов рынка труда.

Ключевые слова и словосочетания: рынок труда, глобализационные процессы, социокультурные контексты, образовательные практики, государственное управление.

$$
\text { И }
$$
нтеграция России в мировое пространство, и в частности ВТО, встречает не только сопротивление определенной части общества, но и превратно понимается отАельными сторонниками ее необходимости. Репрезентируется упрощенное понимание
} 
сущности интегративных проџессов, связанной с попыткой сведения вопроса к подсчету прибылей и убытков. МежАу тем суть не в том, что получит или потеряет сегодняшняя российская экономика, а как участие в глобальных мировых процессах стимуиирует ее изменения.

По утверждению Э. Гидленса, «главным сражением XXI в. станет конфликт межАу фундаментализмом и космополитической толерантностью... Терпимость в отношении культурного разнообразия и демократия тесно взаимосвязаны, а демократия сегодня распространяется по всему миру. За распространением демократии стоит глобализация. В то же время, парадоксальным образом, она демонстрирует ограниченность наиболее привычных нам демократических структур, а именно структур парламентской демократии» [1, с. 6]. Заявмяется не только о перепрофицировании производств, но и о пересмотре моделей GR-relations. Классическим примером политического неприятия интеграции в ВТО может служить проект Г. Зюганова [2] ; однако сходные в своей сущности преАставцения стоят и за концепциями, авторы которых (как в случае «Изборского кцуба») артикулируют мояльность Аействующей власти.

В сфере трудовых отношений аналогичное упрощение, искажающее реальное положение вещей, проявляется в сведении сути проблемы к оџенке конкурентоспособности российских граждан на мировых рынках труда, или, в Аругих контекстах, рисков, связанных с трудовой миграцией в Российскую Федерацию. Межлу тем данные аспекты проблемы не имеют самостоятельного значения, носят производный характер.

Аостаточно показательными в этом плане явцяются попытки выявить возАействия интеграции в систему ВТО на рынки труда уже осенью 2012 г. Анамитики Superjob утверждаци, что «отечественному бизнесу придется конкурировать с международными компаниями, что возвращает к необходимости тщательного планирования и управления финансово-хозяйственной деятельностью» [3]. При этом главными трендами стало увеличение безработицы, а также рост спроса на руководителей высшего звена и экономистов. Как отмечается, Аоля безработных соискателей за месяџ выросла до 53,6\%, среди них преобладают женщины (57\%). Высок процент нетрудоустроенных соискателей в возрасте 20-24 мет (33\%), рассчитывающих на рабочие места в сфере юриспруденции, управления персоналом. С. Рощин полагает, что это мокальная ситуаџия, хотя в Аолгосрочной перспективе ВТО способна регулировать отдельные секторы, в частности, может пострадать рынок труда в сфере обрабатывающей промышленности и сельского хозяйства [4] . Условность этих прогнозов, однако, Аостаточно очевидна. Прежде всего, в России нет единого, универсального рынка труда. Средняя оплата специалистов в экономической сфере по Москве порядка 45 тыс. рублей, в то время как в Екатеринбурге - 25 тыс. рублей, разница почти двукратная. Естественно, прежде, чем процессы, связанные с международной интеграцией, непосреАственно повцияют на ситуацию в российской провинџии, они будут существенно опосредованы. «Особое» положение московского рынка труда определяется не в последнюю очереАь, наряду с привилегированным статусом столицы, тем, что Москва к тому же еще и «ворота» в мировой рынок. Если 
интернациональные компании начнут выходить на провинциальные российские рынки, минуя московский «фильтр», такое положение вещей может радикально измениться.

Прогнозы, строящиеся на учете ожидаемых, в связи с изменением положения российской экономики в международном разделении труда, структурных изменений, преАставцяются наиболее очевидными. ОАнако и они должны учитывать как инерцию российского хозяйственного комплекса, так и всю совокупность факторов, опредемяющих присутствие зарубежных фирм, товаров, услуг на российских рынках. В целом снижение ввозных пошиин на 2-2,5\% вовсе не обязательно повлечет за собой массовую товарную экспансию. Проводить парамлели с ситуациями, имевшимися в некоторых странах Африки и Азии, неправомерно, поскольку российская экономика не возникца на пустом месте, под воздействием интеграции в межкАународное разделение труда, но, напротив, развивалась относительно автономно на протяжении ряда десятилетий. Потребность в структурной перестройке быма очевидна еще Ао краха СССР. Наиболее трезво мыслящим экономистам она была понятна и в 1960-е годы, а в начале 1980-х признавалась и высшим руководством страны. Иначе и быть не могло, поскольку та модель индустриализации и перестройки сельского хозяйства, которая была реализована в 1930-е годы, не могла не породить Аиспропорџий. Остаточные воздействия этих диспропорџий, не будучи устранены радикально, и сегодня продомжают оказывать негативное влияние на ситуацию. Конечно, вступление в ВТО - отнюдь не единственный способ подстегнуть реструктуризацию экономики, но, оценивая ацьтернативные возможности, стоит принять во внимание крах всех попыток реформирования советской экономики, преАпринимавшихся с опорой на значительный властный ресурс. Нет ни малейших оснований думать, будто сегодня есть какие-то «оптимацьные» способы осуществить реструктуризацию, не используя своего рода «шоковой терапии».

Кроме того, следует принимать во внимание, что консерватизм в разцичных отраслях имеет разную природу. Есть отрасли, где имеет место очевиАное технологическое отставание от мирового уровня, которое не может быть скомпенсировано без существенных капиталовложений. В то же время есть ситуации, в которых низкая конкурентоспособность российского производства определяется именно защищенностью рынка: нет смысла осуществлять реорганизацию, если все равно нет конкуренции. Именно поэтому оперирование такими глобальными категориями, как «сельское хозяйство», «обрабатывающая промышленность», в подобных случаях явно некорректны. Следует заявцять о конкретных ситуаџиях, причем в ряле случаев отличающихся по разным регионам.

Воздействия интегративных процессов на характеристики рабочей силы, требования к организации трудовых отношений и рынков труда опредемяются прежде всего потребностями согласования наџионацьных моделей с утверАившимися в мировых практиках. Отсутствие «железного занавеса» проявцяется в универсализации притязаний, систем ожиданий работников. При этом анализ динамики китайской экономики демонстрирует масштабы обратного 
воздействия этих изменений на международные рынки в целом. Очевидно, косвенное влияние международной интеграции здесь можно усмотреть, но, еще раз подчеркнем, оно состоит не в непосреАственном влиянии мирового рынка труда на российский, а опосредованных соџиокультурных реакциях.

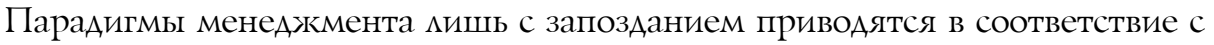
тенденциями, порожденными изменениями в характеристиках рабочей симы. При этом понимание необходимости адаптации международного опыта вырабатывается под воздействием в большей степени сторонних, идеологических соображений, нежели реального учета требований глобализации. Еще в книгах 1990-х годов Ч. Хэнди «The Age of Unreason», «The Empty Raincoat», «Beyond Certainty», «The Hungry Spirit», «New Alchemists» были обоснованы модель «трилистника», «портфель работ» как компоненты новой системы организации труда, не предполагающей Алительной занятности в одной фирме, во многом близкой к идее тотального фрилансерства. Как пишет Ч. Хэнди, работники будущего - это «Аюди, которые оказались вне преАприятий, но работают на них. Я называю их портфельными индивидами. Вместо того, чтобы иАти по пути карьерного роста, им кучше создать товар, ускугу или приобрести навыки, составить портфель, имююстрирующий эти преАложения и искать дмя них покупателей... мы должны будем отказаться от Аинейного - восходящего, как нам хотелось бы думать - характера наших биографий. Портфельный образ деятельности не имеет ничего обшего с минейным, когда одна работа ведет к Аругой - кучшей, а в конџе нас ждет нечто под названием успех (или провац). Аинейный характер постепенно утрачивают и Аругие сферы жизнедеятельности, одни из которых называют семьей, Аругие - развлечением, третьи - обязанностями» [5].

Большая часть этих трудов издана в России, однако адаптация содержашихся в них идей оставляет жекать мучшего. Парадоксом при этом является то, что практики опережают теоретическое осмысление положения вещей. Статьи 310-312, предкагаемого нового Трудового кодекса РФ впервые регумируют отношения, возникающие в связи с Аистанџионной работой. ОАнако, как вполне справедливо отмечается критиками проекта, при этом работодатели получают возможность экономить на «соџиальных пакетах», таким образом, перекладывая на государство решение проблем, связанных с обучением работников, страхованием рисков [6] .

Вместе с тем универсализация рынков вмечет за собой и стандартизацию норм, определяющих условия труда. Убедительнейшим доказательством этого тезиса служит скандал вокруг «дема Foхсопn». Моноспектакль М. Аэйзи «Агония и экстаз Стива Ажобса», вызвавший мощный международный резонанс [7], был посвяшен критике условий труда на заводах Foxconn, одного из ведущих поставщиков комплектующих лмя Apple. Самое примечательное, однако, - сам резонанс как таковой. Абсолютно очевидно, что даже тридцать мет назад масштабы обсуждения были бы совершенно иными; между тем условия труда на предприятиях большинства стран тогда были никак не цучше, чем описанные М. Аэйзи. В данном случае важно не то, в какой мере М. Аэйзи искусственно драматизировал ситуаџию, а сколь масштабные ресур- 
сы были использованы Apple и Foxсonn, чтобы его дезавуировать [8]. 3Аесь в действии наблюдается механизм принципиально нового типа регулирования трудовых отношений.

Россия нужАается в новой целостной конџепџии политик в сферах труда и занятости. Ключевые перспективы такой конџепции должны быть связаны с адаптацией к тенденџиям индивидуализаџии карьерных стратегий и мотиваций трудовой деятельности, новым моделям миграции рабочей силы; парадигмам менеджмента, адекватным кастомизаџии производств, ориентаџии на «портфолио работ», гибкие формы занятости. При этом важно согласование всех уровней разработки и реализации политик в сферах труда и занятости.

ОАним из наиболее важных аспектов такой политики становится перестройка системы образования. По данным Института экономики РАН, «измишек» специалистов высшей квалификаџии в 2004 г. составил 2 млн человек, идет тенденция к увеличению [9]. Анализ положения безработных различных категорий показал, что специалисты с высшим образованием находятся в мучшей ситуации. Во-первых, образование значительно снижает риск и проАомжительность безработиџы. Во-вторых, оно направлено на развитие таких качеств индивида, как коммуникабельность, способность принимать самостоятельное решение, наиболее рационально распределять время. В-третьих, образование позволяет обрести больше свободы и уверенности в себе, развивает гибкость, терпимость к Аругим Аюдям, уважение к культурным ценностям, положительно влияет на семейную жизнь индивида, жизнь общества в целом, способствуя большей ее стабильности.

А.Г. Бермус пишет, что сегодня в России возникает парадоксальная ситуация, когАа индивидуализаџия мичности сопровождается ее маргинализаџией и

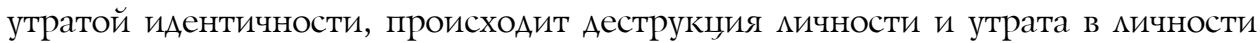
принадлежности чему-либо. Это, естественно, задает новое пространство конкуренции образовательных моделей, которые приспосабливаются к данной ситуации. ОАновременно происходит утрата в культуре временного измерения, в противовес которому утвержАается абсолютность переживания «здесь и сейчас», явцяющегося основанием культа наслаждения настоящим [10] .

Реформа образования в России сталкивается с серьезными трудностями прежде всего не столько в силу раскцада субъективных интересов, не слишком благоприятствуюшего позитивным изменениям, но в решающей мере по причине отсутствия у ее инициаторов ясного понимания поставленной цели. Разумеется, не стоимо бы начинать реформу только дмя того, чтобы обеспечить наилучшие условия Аля интеграции в мировые рынки образовательных услуг и труда. Позиџии России на этих рынках и к началу 1990-х годов были отнюдь не плохи, о чем свидетельствует интерес молодежи целого ряда стран к учебе в России и мировой спрос на российских специалистов. Проблема не в этом. Она и не в коррумпированности образовательных учреждений как таковой: эта коррумпированность - мишь следствие действительно фундаментальных негативных процессов [11].

В образовательных практиках отчетливо проявляется тенденция к обособлению конџептуализаций подготовки государственных служащих, прежде 
всего, естественно, от образовательных программ в сфере собственно менеАжмента. Как вполне справедииво замечает А. Барабашев, «во всем мире "государственное и муниципацьное управление" - это отдекьное направление высшего образования, а не разновидность подготовки менеАжеров» [12] . ОАнако, наряду с безусловно верными указаниями на наличие в программах подготовки менеАжеров курсов, явно изАишних Аля будущих государственных служащих, и, наоборот, отсутствии необходимых Аля получения ими спещифических навыков, продуцируются спорные, как представляется, положения, прежде всего касающиеся «принципиальных отличий государственного управмения от бизнеса и менеджмента в частном секторе по морацьно-этическому настрою» [12] .

В современных условиях речь Аолжна идти о реконструкщии существенно более глубокой. Она проектируется по трем возможным направлениям. Первое предполагает введение в сферу государственного управления преимуществ плоских структур: перенос внимания на потребности и перспективы потребителя, первенствующее значение открытых коммуникаций; перехоА от иерархии к командной работе и гибким ацгоритмам; реинженеринг, предпомагающий новое обогащение труда, соединение аналитической деятельности с обслуживанием кмиентов (и реализацию Маастрихтских принципов) [13] .

Второе направление связано с менеАжеризацией и преАполагает слеАующие Аействия: поиск оптимального соотношения политических и профессиональных начал в администрации; децентрацизацию, удешевление, сокращение администрации; маркетизацию значительной части государственной службы; институционацизацию политической роли бюрократии и механизмов реализации ею своих корпоративных интересов [14] .

Третье, менее очевидное и не столь явно прописанное в современной $\Lambda и$ тературе направление может формироваться из ориентаџии на кибернетизацию, последовательную формализацию деятельности в сфере государственного управления. О.В. Анчишкина совершенно справедииво выявляет в российской аАминистративной реформе начала тысячелетия наличие субъектного аспекта, а также значимость соџиального заказа бизнеса [15]. ОАнако, наряду с субъектностью, соџиальные взаимодействия носят системный характер, а соџиальные системы, как мюбые иные, обладают свойством, определенным Н. $\Lambda$ маном как аутопойесис. Аело, разумеется, не в том, что та ици иная система обретает субъектность и стремится адаптироваться, а в естественном отборе адаптивных систем. Акцентирование политического аспекта реформы, как в «десяти заповеАях» А.В. Оболенского [16], при всей своей важности не исчерпывает содержкания реформы, кАючевым моментом которой в реальности становится осуществленный в органах государственной власти функциональный анамиз.

\section{Библиографический список}

1. Гидденс Э. Ускользающий мир. Как глобализация меняет нашу жизнь. М., 2004.

2. Зюганов Г. Глобальное порабощение России, или Глобализация по-американски. М., 2011. 
3. Кадры для ВТО // Новые известия. 2012. 3 окт.

4. Рынок труда в 2013 году - рынок кандидата // NashGorod.ru. 2013. 5 февр. URL: http:// www.nashgorod.ru/news/news56289.html

5. Handy Ch. The Handy Guide to the Gurus of Management. URL: http://www.bbc.co.uk/worldservice/learningenglish/work/handy/handy.shtml

6. Фрилансеры разрушают экономику // Культурная революция. ВГТРК. Видео. URL: http:/tvkultura.ru/video/show/brand_id/20862/video_id/208421/viewtype/picture

7. В Китае поставят свою версию «Агонии и экстаза» Стива Джобса // AppleInsider.ru. 2012. 20 окт. URL: http://www.appleinsider.ru/mike-daisey/v-kitae-postavyat-svoyu-versiyuagonii-i-ekstaza-stiva-dzhobsa.html

8. Корреспондент Marketplace Роб Шмиц посетил Foxconn // AppleInsider.ru. 2012. 9 апр. URL: http://www.appleinsider.ru//korrespondent-mar

9. Брызгалов А.И. О некоторых теоретико-методических проблемах юридических наук на современном этапе // Государство и право. 2004. № 4. С. 17-22.

10. Бермус А.Г. Что есть просвещение для XXI века? // Политическая концептология: журнал метадисциплинарных исследований. 2014. № 2. С. 40-61.

11. Высшее образование Германии и Болонский процесс // Работа. Наука. Образование. URL: http://rabers.ru/obrazovanie_za_rubezhom/obrazovanie_v_germanii/visshee_obrazovanie_ germanii_i_bolonskiy_protsess.html

12. Барабашев А. Подготовка чиновников отличается от подготовки менеджеров // Сайт ВШЭ. URL: https://www.hse.ru/news/13028506.html

13. Старовойтов A.B. Реформирование российской государственной гражданской службы и опыт зарубежных стран. М., 2003.

14. Атаманчук Г.В. Государственное управление. Организационно-функциональные вопросы. М., 2000.

15. Анчишкина О. Бюрократия начинает, но... выигрывает ли? // Отечественные записки. 2004. № 2 .

16. Оболенский A.B. Нам нужна бюрократия, но публичная, а не «государева» // Отечественные записки. 2004. № 2. 